\title{
Resepsi Remaja terhadap Pornografi dalam Film Indonesia
}

\author{
Tri Hastuti Nur Rochimah dan Fajar Junaedi \\ Dosen Ilmu Komunikasi - Universitas Muhammadiyah Yogyakarta
}

\begin{abstract}
Abstrak
Softcore pornography menjadi jenis pornografi yang lazim ditemui dalam film Indonesia. Maraknya pornografi menyebabkan negara akhirnya memilih memberlakukan Undangundang Pornografi, yang kemudian mengundang banyak kontroversi. Ketidaksepakatan tentang pornografi ini menjadikan penelitian tentang resepsi penonton terhadap film Indonesia yang bermuatan pornografi, sebagaimana penelitian tentang resepsi penonton terhadap pornografi dalam film Mafia Insyaf dan Rintihan Kuntilanak Perawan. Dengan menggunakan analisis resepsi diperoleh hasil para informan cenderung berada dalam posisi negosiasi dengan menyatakan bahwa film Mafia Insyaf dan Rintihan Kuntilanak Perawan adalah film yang bisa dikategorisasikan sebagai softcore pormography.
\end{abstract}

Kata kunci : pornografi, analisis resepsi, film

\begin{abstract}
Softcore pornography became kind of pornographic on Indonesia movies. The rise of pornography led eventually chose enforce state laws Pornography, which is then invited a lot of controversy. Disagreements about pornography makes research on audience reception of the Indonesian film pornographic contents, as well as research on audience reception against pornography on movie of Mafia Insyaf and Rintihan Kuntilanak Perawan. Reception analysis obtained using the following results : the informants tend to be in a negotiating position by stating that the Mafia Insyaf and Rintihan Kuntilanak Perawan are films that can be categorized as softcore pornography.
\end{abstract}

Key words : pornography, reception analysis, movie

\section{Pendahuluan}

Film Indonesia sebagai sebuah entitas industri budaya sempat mengalami mati suri di era tahun 1990-an. Kematian sesaat film Indonesia pada dekade ini ditandai dengan anjloknya jumlah produksi film dalam negeri yang diproduksi. Krisis moneter yang melanda Indonesia pada tahun 1997-1998 semakin membawa film Indonesia ke dalam lubang kematian yang kian mendalam. Biaya produksi yang mahal, sebagai akibat dari mahalnya biaya pasca-produksi yang umumnya masih perlu dilakukan di luar negeri serta turunnya daya beli masyarakat untuk menonton film di bioskop, sebagai akibat dari kemampuan daya beli masyarakat yang jatuh menjadi dua di antara beragam penyebab yang membuat film Indonesia mengalami keterpurukan di masa ini.

Pada perkembangan selanjutnya, film Amerika Serikat menancapkan kukunya di Indonesia. Dengan merunut sejarahnya, para pebisnis dari Hollywood datang dengan mendompleng paket bantuan teknis bernama Technical 
Cooperation Administration (TCA) di tahun 1950 dengan nilai bantuan sebesar lima ratus ribu dollar Amerika. Sebagai imbalan dari bantuan ini, maka kran impor film Hollywood secara massif dibuka melalui kontrol monopoli yang dilakukan oleh American Motion Picture Association in Indonesia (AMPAI). Menurut beberapa laporan terpercaya menunjukan bahwa 600 sampai dengan 700 film Amerika masuk ke Indonesia sepanjang tahun 1950 sampai dengan 1955 (Sen,1994: 25).

Banjir film dari Hollywood ini telah mengakibatkan film Indonesia mendapatkan pesaing yang berat. Dari aspek teknis, industri film Hollywood mempunyai kemampuan yang lebih tinggi karena mereka jauh lebih mapan. Persaingan yang semakin kompetitif dengan film Hollywood dan juga film impor lain, terutama juga dari India dan Taiwan menjadi tantangan tersendiri bagi industri film di dalam negeri. Salah satu siasat yang ditempuh secara instan oleh industri film Indonesia adalah dengan memasukan unsur pornografi dalam scene-scene film Indonesia.

Softcore pornography menjadi jenis pornografi yang lazim ditemui dalam film Indonesia. Peredaran jenis pornografi ini bermula dari film-film Indonesia yang diputar di gedung bioskop yang mulai berani mempertontonkan adegan panas dalam scene-scene-nya. Di tahun 1988, film Pembalasan Ratu Laut Selatan yang dibintangi oleh Yurike Pratisca menggegerkan masyarakat, karena berani menampilkan adegan yang dikategorikan sebagai softcore pornography (Lesmana, 1995: 5).

Selain dibuat dalam format pita selulloid untuk pemutaran di gedung bioskop, film ini juga dibuat dalam format pita video. Di berbagai rental video pada dekade 1980-an sampai dengan pertengahan dekade 1990-an, film-film Indonesia menghiasi berbagai rak rental videodengan beragamjudulyangsemakin berani. Pada tahun 1994 misalnya, dari 26 judul film yang diproduksi, sekitar $80 \%$ di antaranya berbau pornografi dan kekerasan (Lesmana,1995:1). Beberapa judul film Indonesia di masa ini adalah, Ranjang yang Ternoda, Ranjang Pemikat Asmara, Janda Kembang, Skandal Iblis, Misteri Permainan Terlarang, Akibat Hamil Muda dan Sorgaku Nerakaku.

Sebenarnya di masa ini Badan Sensor Film (BSF) memiliki peran besar dalam sensor film yang diproduksi atau diimpor ke Indonesia. Setiap film yang diproduksi di dalam negeri maupun yang diimpor harus dipresentasikan dulu ke BSF, untuk kemudian dilihat oleh sebuah komite kecil yang umumnya terdiri dari tiga orang. Jika ketiga anggota komite kecil ini tidak dapat menentukan layak tidaknya sebuah film beredar, maka film yang belum ditentukan kelayakannya untuk beredar di masyarakat akan ditentukan oleh keseluruhan anggota BSF (Sen,1994:67).

Dilihat dari sejarahnya institusi sensor memang lekat dengan kepentingan politik, sehingga tak ayal jika kemudian isu pornografi dalam perjalanannya agak terabaikan dalam regulasi sensor, walaupun dalam berbagai pemberitaan media massa isu pornografi selalu menjadi isu yang mengemuka dalam persoalan sensor. Hal ini memang bisa dimaklumi karena selama masa Orde Lama dan lebih terutama di masa Orde Baru, isu politik dalam film yang beredar di Indonesia merupakan isu sensitif. Gunting sensor lebih tajam dalam isu politik yang dianggap membahayakan stabilitas negara dan serempak sensor 
yang menggunting isu politik dalam film ini tidak di-blow up dalam pemberitaan di media massa. Sekali lagi ini dilakukan tentu dengan alasan menjaga stabilitas negara. Ini berbeda dengan isu pornografi yang saat tersandung badan sensor secara terbuka lebih banyak mendapat porsi pemberitaan di berbagai media massa, walaupun sebenarnya perhatian negara terhadap isu pornografi tidak sebesar dengan isu politik. Sebelum melihat bagaimana regulasi tentang pornografi terabaikan, ada baiknya kita melihat bagaimana sebenarnya institusi sensor film terbentuk di Indonesia.

Institusi sensor, dengan berbagai nama yang berbeda, telah eksis dalam perfilman Indonesia sejak industri film di Indonesia lahir. Artinya, usia sensor nyaris sama dengan usia perfilman Indonesia. Badan sensor film pertama dibentuk oleh pemerintah kolonial Belanda di tahun 1925. Di masa revolusi kemerdekaan tahun 1945 sampai dengan 1949, pemerintahan Republik Indonesia yang usianya masih sangat muda bahkan juga telah memiliki badan sensor walaupun selama tahun-tahun revolusi fisik hanya ada dua film yang diproduksi (Sen, 1994: 67).

Badan sensor di masa pemerintahan kolonial Belanda sampai dengan masa Orde Baru memang kelihatan lebih digunakan sebagai perangkat negara untuk melakukan sensor terhadap isuisu politik yang berkembang melalui pita film. Tidak aneh jika kemudian berkembang tekanan kepada BSF untuk lebih terbuka kepada publik. Tekanan kepada BSF inilah yang kemudian mendorong institusi sensor ini untuk membuka diri kepada publik dengan salah satunya menerbitkan buletin bernama Berkala BSF pada bulan Agustus 1971 (Sen, 1994: 68).
Jika merujuk kepada ordonasi pemerintah kolonial Belanda tahun 1940, sensor diformulasikan sebagai usaha untuk melawan bahaya atas moralitas dan bahaya terhadap masyarakat yang berhubungan dengan pemutaran film. Ordonasi ini kemudian mengindikasikan bahwa setiap film yang akan dirilis untuk masyarakat harus memenuhi tiga perspektif yaitu moralitas, keamanan publik, dan dapat diterima dengan perspektif lain yang berhubungan dengannya. Pada tahun 1977 dikeluarkan peraturan menteri yang dinamakan sebagai Pedoman Sensor. BSF kemudian mengelaborasi peraturan menteri ini ke dalam Kode Etik BSF di tahun 1981 (Sen,1994:69).

Pada waktu ini, BSF mengumumkan bahwa mereka akan lebih menekankan pada sensor yang berhubungan dengan seks dan kekerasan dalam film, di mana memang Kode Etik BSF memiliki satu bagian yang mengatur tentang pornografi dan larangan terhadap muatan pornografi dalam film, namun kebanyakan regulasi yang ada masih berorientasi kepada isu keamanan negara. Ini bisa dilihat dari berbagai aturan yang ada yang menginstruksikan film untuk dilarang beredar di Indonesia jika dianggap membahayakan persatuan Indonesia, mengancam pembangunan nasional dan bernuansa isu suku, ras dan agama (Sen,1994:69).

Puncak trend film porno, yang memposisikan perempuan sebagai obyek eksploitasi, berlanjut pada dekade 1990-an. Softcore pornography menjadi genre film yang mampu bertahan di tengah gempuran film Hollywood dan daya beli masyarakat untuk membeli tiket bioskop yang semakin menurun. Perkembangan teknologi, yang ditandai dengan kemunculan cakram digital 
dalam format VCD menjadi tantangan baru dalam dekade ini. Masyarakat yang daya belinya turun lebih memilih untuk menyewa kaset VCD dari rental daripada membeli tiket bioskop. Fenomena lain yang tidak bisa dilupakan adalah pembajakan yang merajalela di Indonesia. Cakram VCD bajakan dijual bebas di berbagai sudut jalan oleh para pedagang kaki lima. Kompilasi dari berbagai faktor inilah yang menyebabkan film Indonesia semakin terpuruk (Junaedi, 2010: 5).

Jika dibandingkan dengan era 1990an, kondisi perfilman Indonesia sudah jauh berbeda saat ini. Produksi film kembali menggeliat secara kuantitas. Secara kualitas, penyelenggaraan Festival Film Indonesia (FFI) memberikan penanda bahwa film Indonesia patut diperhitungkan. Sayangnya, isu pornografi yang menjual seksualitas juga menggeliat berbarengan dengan kebangkitan film Indonesia. Jika dulu ikon bom seks bernama Suzanna, Yurike Pratisca dan Sally Marcellina, maka kini julukan tersebut melekat pada Dewi Perssik, Andy Soraya, Julia Perez dan artis-artis lain yang berani tampil berani dalam scene film yang mereka bintangi. Kebangkitan dengan diboncengi film murahan yang dibuat secara instan untuk sekedar meraup penjualan tiket membawa film Indonesia pada elegi (Junaedi, 2010: 5).

Penelitian ini berusaha mengkaji pada sisi khalayak, yaitu bagaimana penerimaan khalayak terhadap filmfilm Indonesia yang dikategorikan sebagai softcore pornography. Dengan menggunakan perspektif konstruksivionis, penelitian ini melihat bagaimana decoding-encoding dari teks film dan khalayak dengan informan mahasiswa yang berbeda-beda. Latar belakang informan adalah mahasiswa Ilmu Komunikasi yang SMA-nya berasal dari sekolah berbasis agama dan sekolah negeri serta pertimbangan gender, yaitu laki-laki dan perempuan. Mereka berinisial Rio (laki-laki dengan latar belakang SMA Negeri), Eki (lakilai, berlatar belakang SMA pesantren), Intan (perempuan, berlatar belakang SMA Negeri dan Tita (perempuan, berlatar belakang SMA pesantren). Film yang menjadi bagian dari penelitian ini adalah Rintihan Kuntilanak Perawan dan Mafia Insyaf, dua film yang banyak berisi adegan-adegan panas.

\section{Pembahasan}

\section{Decoding Film Rintihan Kuntilanak Perawan dan Mafia Insyaf}

Film Rintihan Kuntilanak Perawan di produksi oleh K2K Production. Kru utama dari film ini adalah sebagai berikut produser : KK Dheeraj, sutradara : Yoyo, pemain utama: Tera Patrick (Alice), Angel Lelga (Lilly), Catherine Wilson (Tania), Andreano Philips (Mike). Film Rintihan Kuntilanak Perawan menarasikan tentang pembunuhan berantai yang meninggalkan korbannya dengan tidak wajar.

Bagian awal film dimulai ketika Alice dan Lilly yang diceritakan masih punya ikatan saudara datang ke sebuah klub malam. Sebagaimana di klub malam, para pengunjungnya mengenakan pakaian yang seksi. Alice dan Lilly berkali-kali dishoot dalam angle medium close up bahkan close up untuk semakin mengukuhkan keseksian mereka, terutama dengan belahan dada yang rendah dan rok yang pendek dan ketat. Sembari minum minuman keras, keduanya berkenalan dengan sebuah band bernama Keren Band yang sedang berusaha mencapai ketenaran dengan cara kotor.

Cara kotor yang dilakukan Keren Band, yang dimotori Mike, adalah 
dengan menggelar ritual pasugihan gadis perawan untuk mencapai keinginan yang dimaksud. Dari situlah Mike dan kawankawannya mencari korban pertamanya. Alur film berlanjut, Mike yang juga kekasih Lilly (Angel Lelga) sengaja dikenalkan dengan Alice (Tera Patrick). Tanpa basa-basi, Alice yang masih kakak kandung Lilly itu masuk dalam perangkap bujuk rayu Mike untuk menjadi tumbal pasugihan menaikkan pamor band yang diisi Mike tersebut.

Sejak ritual ini, Keren Band meraup kesuksesan. Sebaliknya Alice yang dijadikan tumbal dalam ritual pesugihan menjadi sasaran arwah penasaran. Awalnya Lilly menemukan kejanggalan ketika sedang mandi. Adegan mandi dan keluar dari kamar mandi yang dilakukan Lilly menampilkan Lilly hanya memakai handuk yang diikatkan pada tubuhnya. Dari sini, Alice mulai muncul dengan diselingi darah dan adegan persenggamaan yang divisualisasi ketika Alice mengenakan lingerie dan menggoda lawan jenisnya serta kemudian melakukan percumbuan.

Adegan persetubuhan dilakukan Alice dengan korban-korbannya menjadi jalinan cerita yang diulang-ulang. Alice ditampilkan dengan balutan lingerie yang menggoda mata lelaki untuk mendekatinya. Sebagaimana film panas Indonesia lainnya, adegan ah-ih-uh-eh-oh ditampilkan di sejumlah adegan, terutama ketika Alice bersetubuh dengan calon korbannya. Bedanya, kini adegan ah-ihuh-eh-oh dilakukan oleh seorang bintang porno tenar dari Amerika Serikat dalam film produksi Indonesia.

Lilly mencoba menyelidiki dengan mengawali bertanya pada Alice. Dialog antara mereka dilakukan di sebuah pinggir kolam renang, tentu dengan balutan pakaian renang yang mereka kenakan. Awalnya Alice tidak mengaku tentang apa yang terjadi. Akhirnya Lilly berusaha menyelidiki bersama Tania. Lilly dan Tania berusaha membebaskan pengaruh makhluk halus dalam raga Alice ketika Alice akan menghabisi korbannya, setelah Alice melakukan adegan percintaan dengan calon korbannya.

Film Mafia Insyaf merupakan film bergenre action yang berbumbu komedi ini telah dirilis pada 28 Oktober2010 dengan sutradara Otoy Witoyo. Film ini dibintangi oleh Tora Sudiro, Atiqah Hasiholan, dan Indah Kalalo. Film ini sebenarnya diperuntukkan untuk usia di atas 18 , namun dalam kenyataannya film ini juga ditonton oleh remaja di bawah usia 18 tahun. Secara singkat film bercerita tentangperjalananseorang pemimpingeng Kapak Ungu yang diketuai oleh serorang perempuan yang diperankan oleh Indah Kalalo yang sedang terus melawan musuh bebuyutannya yaitu geng Macan Polkadot sebagai geng keluarga yang diketuai oleh Tora Sudiro. Beberapa adegan dalam film ini mengandung pornografi terutama dalam adegan-adegan percintaan dengan lawan mainnya.

Adapun sinopsis film ini diawali dengan adegan para perempuan cantik berpakaian renang sedang dalam pose berjalan-jalan di pinggir kolam renang, tidur di atas ban dan senam persiapan berenang; di-shoot satu persatu dari jarak jauh kemudian closed up. Sebagai contoh adegan perempuan tidur di atas ban kolam renang, di-shoot dari secara close up dari ujung kaki sampai dengan mukanya. Setelah scene adagen para perempuan berenang di kolam, kemudian datanglah Kendra meluncur ke dalam kolam dan disambut oleh para gadis yang mengerubutinya sambil tertawa-tawa. 
Scene selanjutnya adalah adegan Selma seorang sersan mayor polisi yang datang ke hotel gerombolan geng Kapak Ungu atas undangan ketua geng Kapak Ungu agar bersedia membantu geng Kapak Ungu. Namun tawaran tersebut ditolak oleh Selma. Penolakan ini membuat ketua geng Kapak Ungu marah, dan kemudian memanggil anggota gengnya untuk melumpuhkan Selma dengan cara memaksa memberi minum yang memabukkan. Dalam scene ini diperlihatkan bagaimana dua anak buah geng Kapak Ungu memaksa memberikan minuman kepada Selma dan memaksa membuka baju Selma. Namun akhirnya Selma dapat meloloskan diri di tempat parkir. Terjadilah pekelahian di tempat parkir. Dalam perkelahian tersebut, datanglah kepala Geng Macan Polkadot yaitu Kendra yang dimainkan oleh Tora Sudiro, membantu Selma mengalahkan geng Kapak Ungu. Pada akhir perkelahian, Tora Sudiro bisa mengalahkan geng Macan Ungu dan membawa pulang Selma dalam keadaan pingsan.

Di rumah Kendra, Selma tidur di kamar Kendra dengan memakai pakaian yang dipinjamkan oleh Kendra; dan Kendra tidur di samping tempat tidur. Begitu bangun tidur Selma, melihat dirinya menggunakan pakaian yang bukan miliknya, dan di samping tempat tidur ada seorang laki-laki yang belum dikenalnya. Selma kaget dan marah. Memang Selma dibawa oleh Kendra dari tempat parkir dalam kondisi pingsan, sehingga tidak sadar ketika Kendra mengganti pakaiannya yang robek dan menidurkannya di tempat tidur Kendra. Namun akhirnya setelah dijelaskan oleh Kendra, Selma mengerti dan segera pamit pulang setelah dia menukar pakaiannya, dengan pakaiannya sendiri.

Setelah Selma melihat hasil CCTV yang menunjukkan perkelahian di parkir mobil, di mana Selma dibantu oleh Kendra, Selma kemudian memiliki pandangan yang berbeda terhadap Kendra. Akhirnya Selma mengajak Kendra untuk kencan dan mereka memulai hubungan spesial. Untuk mempercantik diri, Selma ingin membesarkan payudaranya. Dalam film ini ditunjukkan bagaimana Selma membesarkan payudaranya dengan krim pembesar payudara; dan selanjutnya digambarkan bagaimana Selma dan Kendra naik motor jalan-jalan di Jakarta sementara payudara Selma masih sakit akibat pembesaran payudara. Dalam adegan-adegan selanjutnya ditampilkan bagaimana hubungan mesra antara Selma dan Kendra di samping perseteruan antara gank Kapak Ungu dan Macan Polkadot. Hari ke hari hubungan Selma dan Kendra semakin dekat, bahkan ketika mitra kerja Selma melamar Selma, Selmapun menolaknya karena merasa sudah dekat dengan Kendra. Hal tersebut nampak dalamadegan disebuah café, dimana teman Selma ingin melamar Selma, namun Selma menolaknya dan menyatakan ingin pergi karena sudah memiliki janji dengan orang lain; yaitu Kendra. Selama membangun hubungan dengan Kendra, Selma belum mengetahui siapa sesungguhnya Kendra yang sebenarnya.

Merasa diabaikan oleh Selma, mayor polisibawahan Selmamencoba mendekati ketua genk Kapak Ungu. Mayor polisi ini mendatangi ketua geng Kapak Ungu yang sedang pijat di rumahnya. Dalam adegan tersebut diperlihatkan ketua genk Kapak Ungu dipijat oleh seorang perempuan yang hanya menggunakan bra dan celana dalam, sementara ketua genk Kapak Ungu menggunakan baju renang. Digambarkan sebagai perempuan yang menggoda, selanjutnya ketua genk Kapak Ungu berenang dan disusul oleh mayor 
polisi. Di kolam renang ditampilkan adegan di mana mayor polisi sedang merayu ketua geng Kapak Ungu untuk memulai hubungan seksual.

Hari ke hari hubungan Selma dan Kendra menjadi dekat. Untuk menutupi identitasnya, Kendra mengaku kepada Selma bahwa bekerja di sebuah yayasan sosial. Selma pun juga tidak membuka identitas dirinya. Selma mengaku bekerja sebagai pegawai negeri. Sampai akhirnya Selma mengaku bahwa dia sebenarnya polisi yang menyamar untuk mengungkap kasus-kasus penyelundupan, penggelapan pajak dan mafia. Kendra terkejut mengetahuinya. Selma shock mengetahui identitas Kendra yang sebenarnya. Kendra berjanji pada Selma, jika suatu saat dia terlibat urusan kriminal, Selma boleh menangkap dengan tangannya sendiri. Mereka berdua berada dalam kondisi dilematis, karena sudah merasa saling dekat, saling membutuhkan dan saling mencintai. Kehadiran Selma dalam kehidupan Kendra membuat hidup Kendra semakin bergairah.

Sebenarnya Kendra sudah berperilaku untuk insyaf dan hal tersebut sudah disampaikan kepada orangtua dan juga saudara-saudaranya. Dia ingin mengubah jalan hidupnya, dan tidak mau lagi terlibat dalam kegiatan-kegiatan kriminal yang selama ini dilakukan oleh genknya. Sayangnya Kendra terpaksa terlibat dalam perkelahian ketika kedua adiknya diculik geng Kapak Ungu. Sesuai janjinya, Kendra membiarkan Selma menangkapnya. Selma sedih mendapati kenyataan itu. Kendra, Romi, dan Jodi menjalani pengadilan. Mereka berhadapan dengan Bobi, jaksa yang jatuh hati pada Selma yang menjadi jaksa penuntut dalam kasus perkelahian antar gank itu. Namun ternyata nasib baik berpihak pada Kendra, dimana ternyata terungkap di pengadilan bahwa ada permainan atau persekongkolan antara genk Kapak Ungu dengan mayor polisi; yang terlihat pada rekaman CCTV. Akhir dari kisah ini seluruh anggota genk ditangkap dan ketua genk Kapak Ungu dan Mayor polisi dijebloskan ke penjara. Sudah bisa ditebak bagaimana akhir dari kisah cinta Selma dan Kendra. Akhirnya mereka hidup bahagia karena Kendra sudah insyaf dan kembali menjalani kehidupan yang bahagia dengan Selma. Untuk menunjukkan kebahagiaan tersebut, digambarkan bagaimana mereka berdua bermesraan dan pacaran di pinggir pantai, misalnya Kendra menggendong Selma di pinggir pantai.

Dalam film ini memang terlihat bagaimana Indah Kalalo yang berperan sebagai ketua genk Kapak Ungu tampil vulgar dan melakukan adegan syur dalam film Mafia Insyaf, terutama pada adegan bermesraan antara Indah dengan Sersan Mayor di kolam renang. Dalam beberapa scene film ini menunjukkan atau lebih tepat mengeksploitasi keseksian tubuh perempuan baik oleh Indah Kalalo (ketua genk Kapak Ungu) dan Selma seorang polisi.

\section{Encoding terhadap Film Rintihan Kuntilanak Perawan dan Mafia Insyaf}

Film Rintihan Kuntilanak Perawan adalah sebuah film yang dibintangi oleh artis film porno dari Amerika Serikat, Tera Patrick. Penggunaan figure Tera Patrick dalam film Kuntilanak Perawan adalah kelanjutan penggunan bintang porno yang sukses mengangkat film karena kehebohannya telah menjadi publisitas yang gratis bagi produser film. Adalah film Menculik Miyabi yang mengawali penggunaan bintang porno sebagai pemeran dalam film Indonesia kontemporer. 


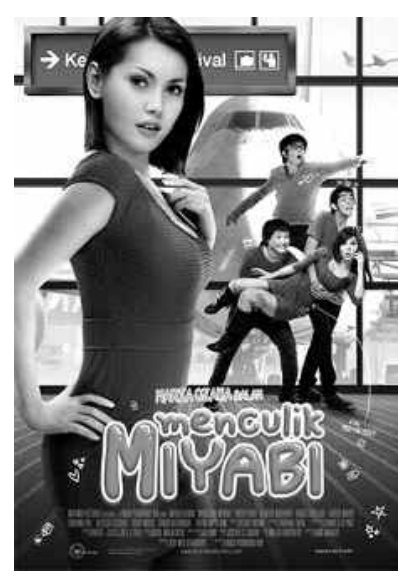

\section{Cover film Menculik Miyabi}

Dari cover film Menculik Miyabi di atas secara jelas terlihat menjual sosok Miyabi untuk menarik minat penonton. Walaupun pada kenyataannya penonton akhirnya tertipu karena sosok Miyabi hanya muncul selintas dalam film tersebut. Film inimengundang kehebohan terutama penolakan dari kalangan Islam dan kaum konservatif.
Keberhasilan film Menculik Miyabi kemudian berusaha diikuti oleh industri film dengan merilis film Rintihan Kuntilanak Perawan yang dibintangi oleh Tera Patrick, Angel Lelga dan Catherine Wilson. Cover dan poster fim Rintihan Kuntilanak Perawan memperlihatkan kemiripannya dengan cover film Menculik Miyabi.

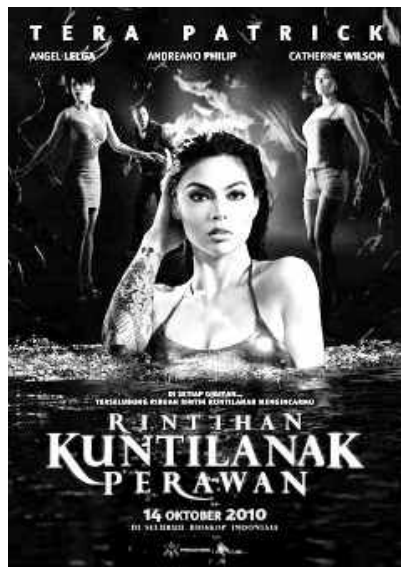

\section{Poster film Rintihan Kuntilanak Perawan}

Berkaitan dengan poster film ini ada beberapa komentar dari informan yang didapatlan dari rekam FGD yaitu :

" (Poster film) tidak porno, karena baju masih sopan, karena u can see meskipun menonjolkan buah dada" (Tita).

"Tera Patrick digunakan menjual, dikesankan dalam cantik, seksi, pemain terkenal di luar. Memang harus begitu untuk mengambarkan Tera Patrick pantas, kenapa bukan orang Indonesia saja yang dengan baju tertutup" (Rio).

"Tidak tahu orang ini, boleh pernah dengar tentang Tera Patrick, janganjangan dia bintang porno setelah di adegan depan pegang payudara. Dibuat sensual covernya" (Intan)

Apa yang dikemukakan oleh infor- 
man memperlihatkan bahwa sosok Tera Patrick bukanlah sosok yang sefenomenal Miyabi. Sehingga agak bisa dipahami jika film Rintihan Kuntilanak Perawan tidak mengundang kontroversi sedahsyat Menculik Miyabi.

Pandangan informan tentang genre film ini juga beragama, sebagaimana yang bias dilihat dalam hasil FGD pada Mei 2012 berikut ini :

"Tujuan pembuat film horor. Film porno karena lebih menampilkan hal-hal yang tidak pantas dilihat oleh orang umum, kategorinya sudah umum. Contoh anak SMA maka menyebabkan dia berimaginasi. Film porno berkedok horror" (Rio)
"Genrenya tidak jelas. Maksudnya produsen mau horor, tapi kategorinya film triller (pembunuhan); agar laku dinamakan film horror karena rakyat Indonesia belum familiar dengan nama film triller"(Eki).

Apa yang dikemukakan oleh informan ini memperlihatkan adanya pandangan tentang adanya muatan pornografi dalam film Rintihan Kuntilanak Perawan. Pandangan ini sekaligus memperlihatkan tentang kesepakatan dari para informan bahwa ini adalah softcore pornography.

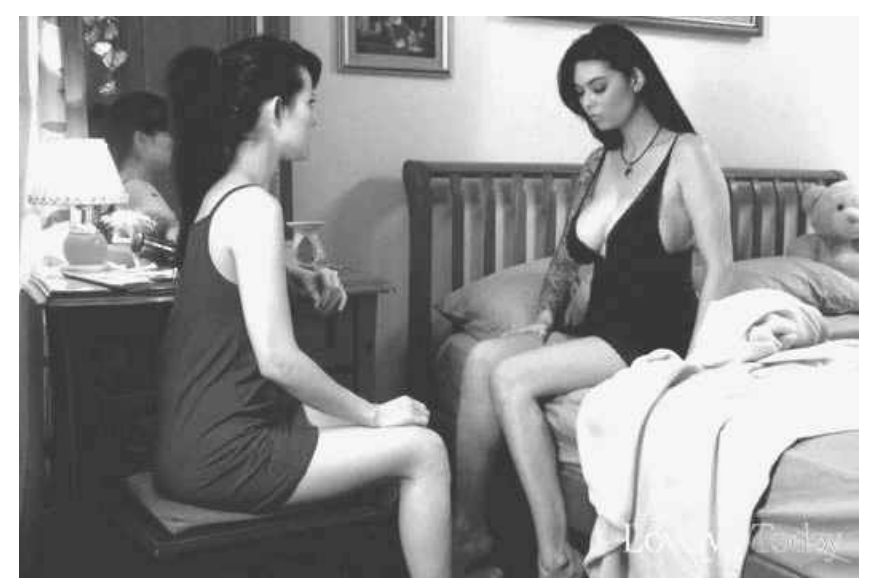

\section{Adegan di tempat tidur dengan baju minimalis yang sering muncul dalam film Rintihan Kuntilanak Perawan}

Adegan yang sering muncul dalam film ini adalah ketika berada di rumah dengan mengenakan lingerie yang ditampilkan secara berulang-ulang. Mengenai hal ini para informan berpendapat sebagai berikut. Rio, mahasiswa Ilmu Komunikasi yang banyak aktif dalam komunitas film dan berlatar belakang SMA negeri menyatakan sebagai berikut :

"Tidak masalah karena film ini ditonton oleh banyak orang, hanya untuk jualan saja. Bangun tidur kenapa harus digambarkan pake lingerie, karena produsen ingin menjual porno" (Rio).
Sebagai orang yang banyak beraktivitas dalam produksi film di kampus dan juga beberapa produksi film di luar kampus, pendapat Rio memperlihatkan pengetahuannya tentang bagaimana film diproduksi dengan rekayasa dengan tujuan menarik minat penonton, dengan salah satu jualan yang paling mudah dijual adalah pornografi.

Pendapat lain dikemukakan oleh Tita, yang SMA-nya adalah pesantren. Menurutnya penggunaan wardrobe seperti dalam adegan tersebut adalah sebagai berikut : 
"Gak pantas, tapi tidak porno. Setting rumah aku, jadi terserah mau ngapain, tapi ketika masuk ruang publik kurang pantas" (Tita)

Pendapat senada juga disampaikan oleh Eki, yang sama-sama berlatar belakang SMA pesantren dengan menyatakan :

"Tidak pantas, tapi bukan porno. Tapi tidak pantas karena ditonton oleh banyak orang.Tidak porno karena tidak secara langsung diekspose, hanya ditunjukkan orang pake lingerie, tidak ditonjolkan payudara secara langsung. Tidak pantas, lingerienya terlalu keliatan tubuhnya, lebih tertutup seharusnya" (Eki)

Intan, informan yang berlatar belakang SMA negeri menyebutkan sebagai berikut :

"Ngga porno, dibuat seakan-akan kebiasaan tertentu, mengada-ada, keluar kamar hanya pakai lingerie" (Intan).

Apa yang dikemukakan oleh keempat informan memperlihatkan adanya negosiasi yang dilakukan oleh khalayak pada isi kedua film tersebut. Mereka tidak serta merta mengiyakan penggunaan pakaian model lingerie dalam film. Justru mereka melihat hal tersebut sebagai pemakaian kostum yang dibuat-buat dan tidak sesuai dengan realitas keseharian

Adegan panas lain yang sering muncul adalah ketika di kolam renang, dimana film ini seringkali menggunakan kolam renang sebagai setting dialog. Saat berada di kolam renang tentu saja, para artisnya menggunakan pakaian bikini yang ketat. Tentang hal ini para informan menyatakan sebagai berikut :

"Porno, karena produsen ingin menjual pornografi, mengundang seseorang untuk berpikir macam-macam, meskipun adegannnya di kolam renang" (Rio).

Apa yang dikemukakan Rio ini jelas memperlihatkan posisinya yang melihat film ini hanya bertujuan untuk menjual konten pornografi pada publik. Isi film yang banyak didominasi adegan dialog di kolam renang mengajak penonton untuk berpikir tentang seks, walaupun dialognya sebenarnya tidak selalu berkaitan dengan seks. Sebagaimana juga yang dikemukakan oleh informan lain :

"Adegan kolam renang, justru mendrive penonton untuk berimaginasi ke arah hubungan seksual, mengkamuflase bentuk pornografi" (Intan).

Pendapat informan lain menyebutkan bahwa pemakaian bikini di kolam renang adalah bagian dari eksploitasi terhadap payudara artis, terutama Terra Patrick.

"Sejak awal memang ingin kenalkan Terra Patrick, maka diekspose payudara Tera yang besar. Niatkan untuk porno, keseluruhan film tidak porno, ada bagian-bagian tertentu yang porno (Eki)

Sebagai sebuah film yang mengekspoitasi Terra Patrick, adegan seks dalam bentuk hubungan seks beberapa kali muncul. Adegan hubungan seks ini bahkan juga dengan sado-masokisme yaitu hubungan seks yang dilakukan dengan kekerasan. Tentang hal ini para informan berpendapat bahwa adegan hubungan seks dalam film adalah porno.

"Porno karena adegan itu tidak untuk di film, tapi untuk suami istri" (Intan)

Pendapat ini memperlihatkan bahwa informan menganggap adegan hubungan seks tidak sepantasnya ditayangkan dalam film karena hanya layak untuk wilayah privat. Tentang sado-masokisme, informan menyebutkan bahwa adegan seperti ini dalam film telah melampaui pornografi di negara Eropa dengan menyebutkan :

"Porno, karena menggambarkan bagaimana sadomasokisme dilakukan, Eropa aja adegan seperti itu limited tidak diperlihatkan umum" (Eki). 
Informan menyebutkan bahwa adegan-adegan tersebut bisa disebut porno. Walaupun bukan film porno, namun dengan menyebutkan bahwa adegan-adegan dalam film Rintihan Kuntilanak Perawan merupakan adegan yang umum dijumpai dalam film porno.

"Porno, Angel (Angel Lelga-peneliti) adegan seperti itu ciri khas film porno, orang yang nonton pasti akan membayangkan" (Rio)

Selanjutnya berkaitan dengan pemaknaan terhadap film Mafia Insyaf yang dibintangi oleh Tora Sudiro dan Indah Kalalo sebagai sebuah film bergenre action ini, semua informan yang nota bene remaja dan berlatar belakang pendidikan Ilmu Komunikasi menyatakan bahwa film ini merupakan sebuah film yang alurnya tidak jelas. Maksud dan tujuan dari film ini pun tidak jelas arahnya. Menurut Tita, mahasiswa Ilmu Komunikasi yang berlatar belakang pendidikan pesantren di Kota Yogyakarta menyatakakan sebagai berikut :

"Film ini kontennya (isi) tidak jelas banget.Pandangannya saya awalnya cerita tentang orangyangjahat kemudian menjadi alim.Ternyata alurnya tidak demikian." (FGD, Mei 2012)

Menurut Tita aur cerita tidak logis, dan tidak nyambung antara judul dengan alur cerita secara keseluruhan. Hal serupa juga disampaikan oleh Rio ketika memberikan tanggapan tentang film ini sebagai berikut :

"Kalau saya melihat, wah ini film bercerita apa sih, bayangan saya adalah ada mafia ketemu cewek kemudian langsung insyaf. Alurnya menurut saya ecek-ecek, kayak sinetron.Hanya bedanya ini film layar lebar dan panjang durasinya. Film ini tidak ada isinya, hanya dibumbui sana-sini, tampaknya produser ingin membuat agar orang tertarik menonton film tersebut. Ada cerita yang membuat saya terharu ketika
Kendra menulis surat untuk bapaknya, namun sayang eksekusinya dangkal sekali. Jadi, bosan juga menontonnya, karena film ini tidak dikerjakan serius hanya menjual Indah Kalalo dan Atikah. "(FGD, Mei 2012)

Secara tegas Rio menyatakan bahwa secara alur juga tidak jelas dan dikerjakan tidak professional. Untuk membuat laris film tersebut, maka sang produser menjual kecantikan dan kemolekan tubuh Indah Kalalo dan Atikah Hasiholan sebagai pemainnya. Penampilan tubuh wanita secara close up pada bagian dada dan paha menjadi salah satu bumbu untuk menjual film tersebut laku. Seringkali seks dalam film Indonesia tidak memiliki hubungan yang jelas. Seks hanya digunakan sebagai bumbu, merupakan tempelan, sehingga kalaupun dihilangkan tidak akan mengganggu jalannya cerita. (Majalah Tempo, 1994: 69)

Pendapat serupa juga disampaikan oleh Eki seorang mahasiswa jurusan Ilmu Komunikasi yang mempunyai latar belakang pesantren modern, seperti penuturannya berikut ini :

"Kalau menurut saya, pertama kali melihat filmnya dari sisi judul sangat aneh, Mafia Insyaf. Spellingnya tidak enak didengar.Filmnya dari sisi ceritanya setengah-setengah.Cerita tidak sesuai dengan judul. Ketika mendengar kata mafia, harusnya dalam film tersebut kan ada God Father, ternyata tidak. Humornya juga tidak lucu, standard sekali. Acting pemain-pemainnya juga pas-pasan. Tidak ada yang spesial dari film ini." (FGD, Mei 2012).

Pendapat senada juga disampaikan oleh Intan, seorang mahasiswi Ilmu Komunikasi. Menurutnya ketika melihat judul film tersebut membayangkan akan melihat film seorang yang insyaf dan menjadi ustadz atau paling tidak seperti film Three Musketer, ternyata tidak; seperti yang disampaikan Intan berikut ini : 
Film ini menjebak ceritanya. Saya kira mafia kemudian ketemu dengan orang yang agamis. Ketika melihat adegan pertama mandi di kolam renang, wah sudah bisa ketebak ini ceritanya pasti tidak bagus. (FGD, Mei 2012)

Secara keseluruhan pendapat informan tentang film ini adalah kurang bagus baik dari sisi isi ceritanya, acting pemainnya,maupunsisipenggarapannya. Para informan menjelaskan secara rinci bagaimana film yang berkualitas dan mereka tidak terjebak pada selera rendah budaya dikarenakan mereka memiliki pengalaman dan pengetahuan bagaimana sebuah film yang bagus sebaiknya diproduksi. Misalnya dari sisi alur cerita logis dan tidak mengeksploitasi tubuh perempuan tanpa alasan yang jelas, dari sisi acting pemain, teknik pengambilan gambar (teknik kamera), music dan ide ceritanya. Pendapat dari informan ini menggambarkan bahwa latar belakang pendidikan dari informan di mana mereka belajar tentang filmologi dalam mata kuliahnya memberikan back ground bagaimana informan memberikan penilaian tentang kualitas sebuah film.

Selanjutnya berkaitan dengan film Mafia Insyaf, bagaimana secara keseluruhan apakah para informan memandang film tersebut dapat dikategorikan film bermuatan porno. Tita yang berlatar belakang pesantren modern di Yogyakarta dan memiliki latar belakang keluarga muslim yang taat menyatakan pendapatnya tentang Mafia Insyaf sebagai berikut :

"Film ini tontonan buat laki-laki banget. Bagi saya kalau bentuk filmnya masih tahap ciuman, fore play itu biasa saja.Ya adalah rasa ingin tahu juga dan berimajinasi.Tapi kalau filmnya sudah sampai telanjang apalagi bersetubuh, pornonya jelas itu, sebagai perempuan saya menontonnya jiijk kalau film-film begitu. Saya eneg (mual di perut :peneliti). Karena saya paham, saya biasa saja menonton film ini." (FGD, Mei 2012)
Berdasarkan pada pengalaman Tita, karena dia sudah biasa menonton film dengan baik yang hard porn maupun soft porn sebagai bagian dari proses pembelajarannya, maka baginya film Mafia Insyaftidak membuatnya horni, atau gambar yang mengundang nafsu, namun biasa saja. Meskipun teman-teman yang menonton katanya menimbulkan horni. Alasan Tita karena dia sudah terbiasa menonton film yang menampilkan adeganadegan yang mengumbar sensualitas perempuan dengan menampilkan buah dada dan paha. Di sekolah Tita juga sudah mendapatkan pelajaran kesehatan reproduksi.

Tidak dapat dipungkiri bahwa sangat mudah di Indonesia untuk menemukan adegan-adegan ciuman, close up paha dan payudara dalam film-film dalam berbagai genre baik remaja/romantis, komedi, action maupun horror. Meskipun demikian, munculnya seks dalam film Indonesia tidak lantas menjadikan film Indonesia sebagai film porno. Film Indonesia yang mengandung unsur seks hanya menjadikan seks sebagai bumbu dalam film dan tidak menggambarkan sebuah ketelanjangan secara utuh dan terang-terangan dalam film. Sedangkan, film porno adalah film yang memang menu utamanya adalah menampilkan sisi ketelanjangan secara terang-terangan.

Senada dengan Tita, Eki yang berlatar belakang pesantren dari keluarga muslim yang shaleh dan berasal dari Kalimantan ini menyatakan bahwa batas porno itu sangat tergantung pada individu masingmasing. Jadi film Mafia Insyaf menurut Eki bisa dikatakan porno dan bisa juga tidak tergantung pada siapa yang melihat; seperti yang disampaikan Eki berikut ini :

"Bagi saya lebih jatuhnya pada individu tentang batas level porno. Menurut saya banyak orang bilang ini gambar seni, namun menurut saya sih tidak porno fulm ini.Lebih tepatnya film semi, itu 
istilah waktu saya SMA. Kalau saya dan teman-teman melihat menyatakan itu film semi. "( FGD, Mei 2012)

Berdasarkan pada pemaknaan Eki terhadap film ini, berdasar pengalaman dia mengakses film dengan temantemannya semasa SMA, menyatakan bahwa film Mafia Insyaf tidak termasuk film porno. Namun dia menamakannya film semi, di mana ada adegan-adegan mempertontonkan paha dan sebagian payudara. Secarajelas Eki menyampaikan bagaimana pemaknaan dia terhadap film tersebut bahwa film tersebut tidak porno namun memang tidak pantas jika dilihat banyak orang; seperti yang disampaikan dalam FGD berikut ini :

"Jawabannya saya tidak porno.Lebih pada tidak pantas karena film ini dilihat orang banyak karena bisa menjadi pembenaran bagi khalayak yang menontonnya." (FGD, Mei 2012)

Pemaknaan ini sejalan dengan yang telah disampaikan sebelumnya oleh Eki bahwa seluruh adegan dan alur cerita dalam film ini bukan porno. Hanya saja perlu dibatasi siapa saja yang boleh menonton ini. Eki berpendapat jika ditonton oleh publik yang belum dewasa maka adegan-adegan yang belum seharusnya ditonton atau dikonsumsi akan ditiru oleh anak-anak yang seharusnya belum boleh menonton. Selama ini film-film Indonesia yang lolos sensor LSF pun ternyata banyak yang mengekpsloitasi seksualitas perempuan, namun penonton juga tidak dibatasi usia baik menonton di bioskop maupun dalam bentuk kaset DVD.

Agak berbeda dengan Eki dan Tita, Intan seorang mahasiswa jurusan Ilmu Komunikasi dari latar belakang abangan dan bersekolah di sekolah umum (negeri) menyatakan bahwa film Mafia Insyaf merupakan film yang porno, seperti disampaikan berikut ini :
"Film itu porno karena mengundang sensasi penonton. Tidak ada hubungan antara judul film dengan alur ceritanya. Efek kameranya ingin cari perhatian, apakah porno atau vulgar ya " (FGD, Mei 2012)

Berkaitan dengan makna porno ini, secara khusus Rio membandingkan dengan film import. Film import dengan adegan yang sama tidak terlihat porno, sementara kalau itu film ini terlihat porno. Di Indonesia misalnya ketika menampilkan perempuan dengan tubuh seksi atau terbuka tidak memiliki makna, hanya sebagai bumbu saja dan ini berbeda dengan film import di mana adegan penampilan tubuh seksi itu memiliki makna; artinya berkaitan dengan alur cerita; seperti disampaikan Rio berikut ini :

"Saya liat adegan vulgar itu porno, berbeda dengan film luar yang tidak pakai baju, namun malah saya liat biasa. Film Indonesia berbeda, ingin menampilkan keseksian, kalau film luar itu kan bagian dari seni sebuah cerita, di Indonesia mempunyai makna yaitu seks hanya sebagai bumbu." (FGD, Mei 2012)

Senada dengan Intan, Rio seorang mahasiswa dari keluarga abangan menyatakan bahwa film tersebut merupakan film porno, karena memang secara sengaja ingin menampilkan adeganadegan tersebut, yang sebenarnya tidak harus ditampilkan, seakan-akan mengadaada; seperti penuturannya berikut ini :

"Kalau menurut saya porno karena tidak ditangkap bahwa film Mafia Insyaf adalah film action. Yang saya tangkap adalah cewek yang seksi. Film porno mernurut saya adalah film yang membuat kita berbeda sebelum dan pas menonton. Kalo Titanic yang saya tangkap ceritanya tapi kalau film ini cuma cewek-cewek saja. Kalau membuat tertarik, deg degan maka saya kelompok kan sebagai film porno." ( FGD, Mei 2012) 
Pengalaman, pengetahuan serta latar belakang dari masing-masing informan yang beragam menajdi faktor yang cukup penting bagi khalayak bagaimana mereka memaknai sebuah film, apakah film tersebut dikategorikan sebagai film yang bermuatan porno, atau cenderung mengarah porno, ataukah tidak.

Selanjutnya berkaitan dengan adegan per adegan dalam film Mafia Insyaf, film ini dibuka dengan adegan mandi di kolam renang. Bagi Rio, adegan dalam kolam renang itu tidak seharusnya seperti ini, meskipun di kolam renang dan menggunakan pakaian renang untuk konteks Indonesia dianggap kurang pantas, karena model baju renang itu macam-macam; seperti dituturkan berikut ini :

"Tentang pakaian, kan ada pakaian yang tidak harus seperti itu, ada pakaian renang tertutup, ada pakaian renang yang lebih pantas dipakai di Indonesia. Intinya kalau ingin menampilkan adegan dikerubutin cewek tidak perlu menampilkan scena yang seperti itu " (Wawancara, Mei 2012)

Pernyataan Rio tersebut menggambarkan bahwa faktor nilai dan pengalaman menjadi faktor yang penting dalam memberikan pemaknaan, sekalipun adegan tersebut di kolam renang namun pakaian renangpun harus sesuai dengan budaya Indonesia yaitu menggunakan pakaian renang yang lebih tertutup. Pemaknaan Rio ini agak berbeda dengan Tita, di mana bagi Tita scene tersebut memang seharusnya begitu apalagi adegannya harus berada di kolam renang; seperti penuturannya berikut ini :

Kembali ke jawaban saya, bahwa adegan itu juga tidak porno. Di pikiran saya memang film ini male gaze. Adegan itu biasa saja, tidak ada maksud porno, meskipun sebenarnya saya tidak suka menonton pas adegan itu.( Wawancara, Mei 2012).

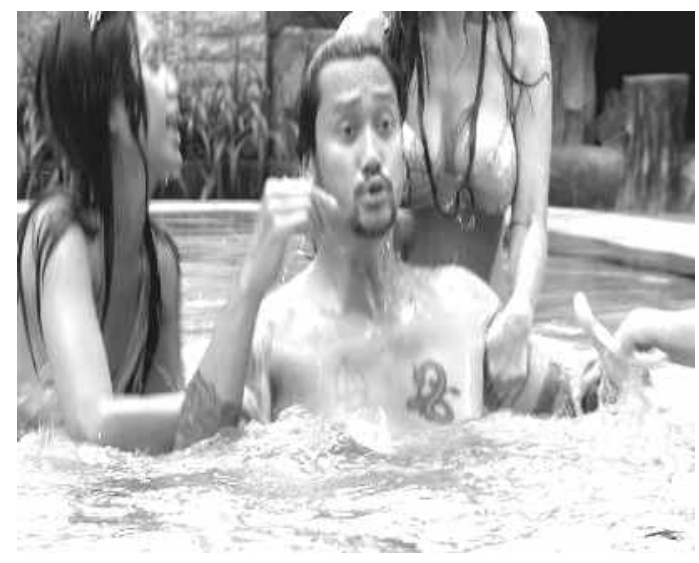

\section{Adegan di kolam renang dalam film Mafia Insyaf}

Sebagai seorang perempuan, Tita merasakan bahwa film ini benar-benar hanya ingin mengeskploitasi tubuh perempuan dengan cara tatapan laki-laki (male gaze). Meskipun Tita mengatakan adegan itu biasa saja, tidak porno namun untuk menontonnya ada perasaan malu.
Pernyataan Tita berbeda dengan apa yang disampaikan Intan, di mana Intan menyatakan bahwa adegan tersebut termasuk porno karena tidak bermakna apapun adegan di kolam renang, hanya bumbu saja yaitu bumbu seks sebuah film. Pernyataan Intan ini sejalan dengan 
pemaknaan Rio terhadap scene ini. Berikut ini apa yang disampaikan oleh Intan :

.....kalau saya adegan tersebut jelas porno. Setelah para perempuan ini mandi di kolam, tidak ada hubungan apapun dengan alur cerita, ya hanya untuk menarik penonton saja adegan ini (Wawancara, Mei 2012).

Sementara itu untuk adegan Tora Sudiro yang memegang kemaluannya yang sedang ereksi, pemaknaan Rio bahwa adegan itu porno.

Menurut Rio adegan ini dianggap porno karena tidak sesuai dengan kultur Indonesia; dan mengapa harus di shoot masturbasi, seperti pernyataannya berikut ini :

.....kalau saya itu porno, kan tidak sesuai dengan kultur Indonesia; mengapa harus ada adegan masturbasi, atau adegan ereksi. (Wawancara, Mei 2012)

Senada dengan Rio, Intan menyatakan itu porno dengan alasan kalau adiknya nonton bisa berbahaya :

.....kalau saya menonton dengan adik saya, saya tutup matanya, karena saya kuatir. Adik saya kan belum pantas menontonnya karena ini tontonan untuk orang dewasa. (Wawancara, Mei 2012)

Berbeda dengan Intan dan Rio, bagi Tita adegan tersebut biasa saja seperti peristiwa biologis. Pengalaman Tita mendapatkan materi tentang kesehatan reproduksi secara mendalam menjadikan dia memaknai bahwa ereksi merupakan proses tubuh yang biasa atau alami. Selanjutnya untuk adegan dimana Selma menggunakan krem payudara, baik Intan, Tita dan Eki menyatakan itu hal yang wajar karena scene-nya ditunjukkan tidak dengan begitu jelas, artinya cukup dengan symbol-simbol saja sudah dapat dipahami. Seperti dinyatakan oleh Eki berikut ini : ....kalau saya sih biasa saja, kayak mempraktekan bagaimana menggunakan krim. Mungkin tidak perlu diperlihatkan adegan, bagaimana Selma memasukkan tangganya di payudara, kan sebenarnya penonton sudah paham. Sama saja dengan iklan pembalut yang dsihoot pantatnya.( Wawancara, Mei 2012).

Berbeda dengan Intan dan Eki, meskipun sama-sama menganggap itu adegan yang wajar, namun alasannya berbeda. Bagi Tita, meskipun ada adegan bagaimana Selma memasukkan tangannya untuk memegang payudara, adegan ini biasa saja karena dilakukan di ruang privat. Point yang ditekankan oleh Tita karena adegan ini dilakukan di ruang privat maka scene-scene yang bersifat pribadipun tidak masalah. Sementara itu untuk adegan di tempat pijat, di mana ditunjukkan pakaian Indah Kalalo dan tukang pijat yang hanya menggunakan pakaian renang, kemudian dilanjutkan dengan adegan di kolam renang ada informan yang menyatakan itu adegan mengarah pada porno da nada yang tidak Bagi Rio scene ini mengarah ke unsur porno, seperti disampaikan berikut ini :

... dari awal dipijat, saya menangkapnya tidak cocok dilihat orang dibawah umur.Demikian juga di kolam renang, adegannya mengarah pada hubungan intim. Apalagi di tempat pijat, sangat jelas diperlihatkan memijat hanya menggunakan bra dan celana dalam, sementara di kolam renang mengarah pada hubungan intim dan mendorong pada imajinasi dan gairah seks. (Wawancara, Mei 2012).

Bagi Rio jika adegan ini mengundang orangberimajinasiataumendoronggairah seks ini termasuk pornografi.Sementara itu bagi Tita dan Eki, scene tersebut wajar, dan dianggap tidak mengarah ke porno. Keduanya menyatakan bahwa adegan 
itu hanya sekedar seksi saja, seperti yang dituturkan :

".....kalau saya melihatnya hanya seksi saja. Kan tidak secara langusng ditunjukkan adegan hubungan intim, hanya foreplay di kolam.Ini permainan imajinasi yang nonton saja, jadi termasuk biasa saja." (Wawancara, Mei 2012).

Pernyataan ini sejalan dengan pemaknaan Tita atas scene tersebut, di mana adegan ini wajar saja karena penonton sudah tahu arah adegan ini kemana, dan hanya saat-saat menuju pada hubungan intim. Selanjutnya dalam film ini dgambarkan bagaimana cara berpakaian yang artis-artisnya terutama Indah Kalalo dan Atikah $\mathrm{H}$ dalam setiap scene, kesemuanya menyatakan bahwa cara berpakaian sebenarnya biasa saja hanya di beberapa adegan terlihat sekali maksud sang sutradara yang sebenarnya ingin mengeksplotasi tubuh perempuan. Menurut Intan, pemaknaan tentang cara berpakaian, problemnya hanya pada pantas dan tidak pantas, sebagai misal ketika berada di kantor menggunakan pakaian yang lebih layak untuk ke pesta/ makan malam daripada ke kantor.; seperti dinyatakan Intan :

"....kalau saya lebih karena tidak nyaman saja menontonnya, tapi karena sudah sering dimunculkan akhirnya kok menjadi baisa, meskipun dalam beberapa scene ada yang tidak pantas pakaiannya artinya suasananya."(Wawancara, Mei 2012)

Sementara bagi Tita, tidak ada masalah dengan cara berpakaian para artisnya karena sudah lumrah pada jaman sekarang, orang menggunakan pakaian semacam itu, yaitu dengan dada rendah dan memperlihatkan paha.

\section{Simpulan}

Pada bagian awal laporan penelitian ini telah disebutkan bahwa pornografi adalahisu yang menyeruakseiring dengan perkembangan jaman. Pornografi selalu menjadi persoalan dalam peradaban manusia, walaupun pornografi telah diperangi dengan massif.

Penelitian ini memperlihatkan hasil yang sebagai berikut :

1) Para informan cenderung berada dalam posisi negosiasi dengan menyatakan bahwa film Mafia Insyaf dan Rintihan Kuntilanak Perawan adalah film yang bisa dikategorisasikan seabgai softcore pornography. Dalam beberapa adegan mereka menyatakan bahwa adegan tersebut bukan adegan porno, namun dalam beberapa adegan yang lain mereka menyatakan bahwa film tersebut adalah film porno.

2) Pandangan para informan ini memperlihatkan gejala dari remaja Indonesia kontemporer yang telah mengkonsumsi content porno dari media yang mereka konsumsi.

3) Latar belakang para informan yang berasal dari kalangan santri dan abangan ternyata tidak jauh berbeda dalam resepsi yang mereka lakukan atas film Mafia Insyaf dan Rintihan Kuntilanak Perawan.

\section{Daftar Pustaka}

Junaedi, Fajar (2007). Komunikasi Massa, Pengantar Teoritis. Yogyakarta, Santusa

Junaedi, Fajar [ed] (2010). Elegi Film Indonesia. Yogyakarta, Lingkar Media dan UAJY

Lesmana, Tjipta (1994). Pornografi dalam Media Massa. Jakarta, Puspa Swara.

Sen, Krishna (1994). Indonesian Cinema: Framing The New Order. London, Zed Books Ltd.

Bambang Bujono, "Seks: dari Bumbu Menjadi Menu," dalam Majalah Tempo : 17 (25 April 1994)

Himawan Pratista (2008). Memahami Film, Yogyakarta: Homerian Pustaka. 